Sholihah, N. R., \& Azizah, I. (2020). The Effect of Effleurage Massage on Primary Dysmenorrhea in Female Adolescent Students. JURNAL INFO KESEHATAN, 18(1), 9-17.

https://doi.org/10.31965/infokes.Vol18.Iss1.310

Jurnal Info Kesehatan

Vol.18, No.1, June 2020, pp. 9-17

P-ISSN 0216-504X, E-ISSN 2620-536X

DOI: 10.31965/infokes.Vol18.Iss1.302

Journal homepage: http://jurnal.poltekeskupang.ac.id/index.php/infokes

R E S E A R C H

Open Access

\title{
The Effect of Effleurage Massage on Primary Dysmenorrhea in Female Adolescent Students
}

\author{
Nur Rahmawati Sholihah ${ }^{1 a^{*}}$, Imroatul Azizah ${ }^{1 b}$ \\ ${ }^{1}$ Midwifery Study Program, Faculty of Health Science, Universitas Jenderal Achmad Yani \\ Yogyakarta, Indonesia \\ ${ }^{a}$ Email address: rahmaherdian127@gmail.com \\ b Email address: azizah578@gmail.com
}

Received: 12 November 2019

Revised: 10 June 2020

Accepted: 23 June 2020

\begin{abstract}
Primary dysmenorrhea is a painful condition during menstruation. It is characterized as cramping and is centered on the lower abdomen. The state may be accompanied by headaches, nausea, vomiting, diarrhea, and mild to severe trembling as it affects daily activities. The dysmenorrhea condition would affect the quality of life of most women. This study aimed to determine the effect of effleurage massage on primary dysmenorrhea of female adolescents in student's dormitory of General Achmad Yani University, Yogyakarta. Method This research used a quasi-experimental approach with pre and post-test for two-group design. A total sample of 58 respondents was divided into the intervention and control groups. The sample determination used simple random sampling. Furthermore, the data is analyzed using the Wilcoxon test. Results this research showed a significant difference between the intervention groups and the control group was found after the intervention group was given the effleurage massage treatment $(p<0.05)$. The conclusion of this research is effleurage massage has a significant effect on reducing pain in the lower abdomen during menstruation (dysmenorrhea). It is recommended to promote effleurage massage as an alternative to non-pharmacological treatment for female adolescents to reduce pain due to their dysmenorrhea.
\end{abstract}

Keywords: Effleurage, Dysmenorrhea, Massage

\footnotetext{
*Corresponding Author:

Nur Rahmawati Sholihah

Midwifery Study Program, Faculty of Health Science, Universitas Jenderal Achmad Yani Yogyakarta

Gang Manggis, RT. 02 Brajan Tamantirto Kasihan Bantul, Yogyakarta, Central Java, Indonesia

Email: rahmaherdian127@gmail.com
}

(CThe Author(s) 2020. This article is distributed under the terms of the Creative Commons Attribution 4.0 International License (http://creativecommons.org/licenses/by/4.0/), which permits unrestricted use, distribution, and reproduction in any medium, provided you give appropriate credit to the original author(s) and the source, provide a link to the Creative Commons license, and indicate if changes were made. The Creative Commons Public Domain Dedication waiver (http://creativecommons.org/publicdomain/zero/1.0/) applies to the data made available in this article, unless otherwise stated. 


\section{INTRODUCTION}

Primary dysmenorrhea is defined as a painful condition amid menstruation that characterized as cramping and centered on the lower abdomen that may be accompanied by other sign \& symptoms such as sweating, headache, nausea, vomiting, diarrhea and trembling, sometimes until severe to disrupt activities (De Sanctis et al., 2015). This dysmenorrhea condition will affect the quality of life of most women. The prevalence of dysmenorrhoea around the world varies between $50 \%$ and $90 \%$ with $38.3 \%$ suffering from severe pain and $58 \%$ suffering from moderate pain (Fernández-Martínez et al., 2018).

The research showed the prevalence of dysmenorrhea in Indonesia is $64.25 \%$, which consists of $54.89 \%$ of primary dysmenorrhea and $9.36 \%$ of secondary dysmenorrhea. The prevalence of dysmenorrhea in Indonesia is around 55\% among the productive age, while $52 \%$ of students in Yogyakarta are unable to perform their activities optimally during menstruation. The results showed 44 respondents experienced dysmenorrhea, mostly experienced moderate dysmenorrhea (29 respondents; 65.9\%) (Abunawas D.W.S \& Khotimah S., 2017).

Risk factors associated with increased severity of dysmenorrhea symptoms consist of menarche, prolonged menstrual periods, blood come-out during menstruation, smokers, and family history of dysmenorrhea. A very high prevalence of dysmenorrhea among adolescents shows that this condition is a public health problem that requires serious attention (De Sanctis et al., 2015).

Pharmacological treatment is an option that is usually given in cases of dysmenorrhea through the administration of pain relief medication (80\%). While nonpharmacological management of dysmenorrhea can be done in various ways, including acupuncture, distraction, deep breathing techniques, guided imagination, biological feedback, music therapy, massage, and compresses. Non-pharmacological pain management is safer. It does not cause side effects like drugs because it involves physiological processes (Abunawas D.W.S \& Khotimah S., 2017).

Effleurage massage is a non-pharmacological method that is considered useful in reducing pain. Effleurage is a gentle, rhythmic massaging technique, pressurized gently toward the distal or bottom. Effleurage aims to improve blood circulation, put pressure on, and warm abdominal muscles, and increase physical and mental relaxation (Murtiningsih \& Andani, 2018).

The research results stated that the effleurage massage technique into the stomach affects decreasing pain intensity for dysmenorrhea. Reduction in menstrual pain occurs after the administration of effleurage massage techniques. It stimulates the skin's tactile fibers so that pain signals can be blocked. Gentle touch and massage are the integration of sensory techniques that are affected by the activity of the autonomic nervous system (Anita, 2017). The research result of 11 respondents, done. Giving the effleurage massage could lower the pain. The stretching treatment also showed the same result. However, a significant difference was not found on those two treatments. The factor of family history has not been entirely described in that paper. Family history was one of some elements of the improving cases of adult dysmenorrhea. The treatment of effleurage massage as a relaxation has also been done to the pregnant women of the third semester as birth preparation and painkilling treatment. Therefore, it is necessary to give effleurage massage to the adolescent female to improve their activity and productivity using strict pain screening to the respondents of the research. Moreover, to 
Sholihah, N. R., \& Azizah, I. (2020). The Effect of Effleurage Massage on Primary Dysmenorrhea in Female Adolescent Students. JURNAL INFO KESEHATAN, 18(1), 9-17.

obtain the comprehensive risk-factor of dysmenorrhea, family history was also studied in this research.

\section{RESEARCH METHOD}

We used a quasi-experimental approach with pre and post-test two-group design. The respondents were divided into two groups, namely the intervention group and the control group. The intervention group was given effleurage massage treatment, and the control group was not given massage effleurage treatment. This study was conducted in April-July. The study population is all students who lived in the female dormitory, who has menstruation pain, normal menstrual cycle, menarche age, normal menstrual duration, and family history of dysmenorrhea. The sample count uses non-matched pairs of comparative analytic, which is :

$$
n 1=n 2=\frac{\left(Z \alpha \sqrt{2 p q}+Z \beta \sqrt{p_{1} q_{1}+p_{2} q_{2}}\right)^{2}}{\left(p_{1}-p_{2}\right)^{2}}
$$

Based on the calculation, the samples are 29 for the intervention group and 29 for the control group. A total of 59 respondents is in the study. The simple random sampling is used in the study. The data were collected from primary data that include pain measurement using the Numerical Rating Scale (NRS). The analysis used to describe the characteristics of respondents using the frequency distribution, bivariate analysis using the Kolmogorov Smirnov test, and non-parametric Wilcoxon test. This study had been subject to a research ethics agreement with number: Skep/032/KEPK/IV/2019.

\section{RESULTS AND DISCUSSION}

Table 1. Frequency Distribution of Respondents Characteristics

Respondents Characteristics

Menarche age (years old)

\begin{tabular}{lrrrr}
\hline$<12$ & 1 & 3.4 & 5 & 17.2 \\
\hline$\geq 12$ & 28 & 96.6 & 24 & 82.2 \\
\hline Menstruation duration & & & & \\
\hline$\leq 6$ days & 8 & 27.58 & 13 & 44.8 \\
\hline$>7$ days & 21 & 72.4 & 16 & 55.2 \\
\hline Family history & & & & \\
\hline Present & 7 & 24.1 & 4 & 13.8 \\
\hline Absent & 22 & 75.9 & 25 & 86.2 \\
\hline
\end{tabular}

Most respondents were $\geq 12$ years old when the first menstruation occurs with $96.6 \%$ and $82.2 \%$ were in the intervention group and control, respectively. The menstrual period mostly more than seven days with $72.4 \%$ in the intervention group and $55.2 \%$ in the control group. 
Table 2. Descriptive Analysis of Pain Reduction in the Intervention and Control Group

\begin{tabular}{llrrrrr}
\hline & Dysmenorrhea pain & \multicolumn{2}{c}{ Intervention } & \multicolumn{2}{c}{ Control } \\
& & $\mathbf{n}(\mathbf{2 9})$ & \% & n (29) & \multicolumn{1}{c}{} \\
\hline Pre & No pain & 0 & 0 & 0 & 0 \\
\hline Mild & 8 & 27.6 & 12 & 41.37 \\
\hline Moderate & 21 & 72.4 & 17 & 58.6 \\
\hline Severe & 0 & 0 & 0 & 0 \\
\hline Post & No pain & 8 & 27.6 & 0 & 0 \\
\hline & Mild & 21 & 72.4 & 12 & 41.37 \\
\hline & Moderate & 0 & 0 & 17 & 58.6 \\
\hline & Severe & 0 & 0 & 0 & 0 \\
\hline
\end{tabular}

The reduction in pain level in the intervention group was mostly from moderate to mild.

Table 3. Analysis of the differences in dysmenorrhea in the intervention group and the control group

\begin{tabular}{|c|c|c|c|}
\hline \multirow[t]{3}{*}{ Dysmenorrhea } & \multicolumn{2}{|c|}{ Group } & \multirow[t]{3}{*}{ p-value } \\
\hline & Intervention & Control & \\
\hline & $(n=29)$ & $(n=29)$ & \\
\hline \multicolumn{4}{|l|}{ Pre } \\
\hline Mean (SD) & $1.72(0.455)$ & $1.97(0.731)$ & $0,463 *$ \\
\hline Median (Range) & $2(1-2)$ & $2(1-3)$ & \\
\hline \multicolumn{4}{|l|}{ Post } \\
\hline Mean (SD) & $0.72(0.455)$ & $1.97(0.731)$ & $0,000 *$ \\
\hline Median (Range) & $1(0-1)$ & $2(1-3)$ & \\
\hline Pain difference & $\mathrm{p}<0.05 * *$ & $\mathrm{p}>0.05^{* *}$ & \\
\hline
\end{tabular}

Descriptions: *) Mann Whitney Test, **) Wilcoxon

There was a difference in pain in the intervention group before and after being given effleurage massage with a result of $p<0.05$, which means there was a significant difference in the pain scale of dysmenorrhea before and after being given effleurage massage.

a. Characteristics of Respondents

Menarche is a physiological state in a woman's first menstrual period. This condition occurs because of the increasing FSH and LH increasing rate, which have the function of stimulating ovarian target cells. Both of these hormones synergize with FSH and LH receptors, which increases secretion and growth rate of cell proliferation (Kumalasari, 2017). The first menstruation is called menarche, with the ideal age of menarche is 12-14 years old. It is called early menarche if the first menstrual period is under 12 years old (Beddu et al., 2015). Furthermore, it is found that menarche age may affect primary dysmenorrhea. The results of the study based on Table 1 characteristics of respondents by age in the control group $\geq 12$ years were 24 respondents $(82.2 \%)$ and in the intervention group were 28 respondents $(96.6 \%)$. These results are consistent with the theory that dysmenorrhea arising during normal menarche age reflects the absence 
Sholihah, N. R., \& Azizah, I. (2020). The Effect of Effleurage Massage on Primary Dysmenorrhea in Female Adolescent Students. JURNAL INFO KESEHATAN, 18(1), 9-17. https://doi.org/10.31965/infokes.Vol18.Iss1.310

$\mid 13$

of prolonged exposure to uterine prostaglandins, where uterine prostaglandins play a major role in dysmenorrhea through increased uterine contractility (Al-Matouq et al., 2019). Based on that, a woman with normal menarche age ( $\geq 12$ years old), her prostaglandin levels will remain stable because of no excessive uterine contractions, hypertonus does not occur, and myometrium will experience vasodilation. (FernándezMartínez et al., 2018)

Menstruation duration is one of the characteristics of respondents that influences the pain of primary dysmenorrhea in adolescents. The results of the study in Table 1 show that menstrual periods $>7$ days in the intervention group were $72.4 \%$, and the control group was $55.2 \%$. Menstruation causes uterine contractions. If the menstrual period is more than normal, then uterine contractions occur longer and more prostaglandins are excreted (Lestari, 2013). This is in line with the study of Kural et al., (2015), which stated that from 100 women suffering from dysmenorrhea, it is shown that $20 \%$ of women had menstrual periods longer than 5 to 7 days. Based on the study illustrating that women with menstrual duration longer than 5 to 7 days had 1.9 times more chance of suffering from dysmenorrhea. Physiological factors cause long menstruation, namely, menstruation occurs due to excessive uterine muscle contraction so that the endometrium in the secretion phase will produce a higher prostaglandin hormone. The longer the duration of menstruation, the more frequently the uterus contracts so that more prostaglandins are released (Kural et al., 2015). Excessive prostaglandin production will cause pain, while uterine contractions that occur continuously can cause the blood supply to the uterus to stop, and dysmenorrhea occurs (Lestari, 2013).

Another factor that influences dysmenorrhea is family history. Family history is a risk factor that can increase the likelihood of dysmenorrhea in women (Dhewi, 2016). The results showed that based on the characteristics of family history in the control group and the intervention group, it was found that respondents in both groups who had dysmenorrhea did not have a family history. The results of this study are inversely proportional to the research conducted by Charu et al., who suggested that $39.46 \%$ of women suffering from dysmenorrhea had family members with dysmenorrhea complaints such as mothers or siblings. Family predisposing factors have a strong correlation with dysmenorrhea pain, especially genetic factors (Charu et al., 2012). The results based on table 1 explain the average respondent does not have a family history, which means that dysmenorrhea pain can occur due to other factors such as psychological factors which will affect other hormones such as vasopressin which is synthesized in the hypothalamus but secreted from the posterior pituitary which will increase contractility of the uterus so that increased uterine contractility will slow blood flow to the uterus until oxygen deficiency occurs. There is an increase in production and stimulates the secretion of the uterus prostaglandin, which ends in painful dysmenorrhea (Fitriana, 2017). Psychological factors that cause dysmenorrhea are generally related to a woman's mental health, such as depression, anxiety, stress, alcohol abuse, and somatic disorders (Bajalan et al., 2019). High levels of anxiety can occur due to lack of external 
support factors, low social support, alexithymia, neuroticism, long menstrual bleeding, family history of dysmenorrhea, and a high diet in caffeine. These factors are important risk factors for women with primary dysmenorrhea (Faramarzi and Salmalian, 2014).

\section{b. Analysis of the Difference Between Dysmenorrhea and Administration of Effleurage Massage}

The results of the study based on Table 3 shows that dysmenorrhea before pretest in the two groups showed no significant difference with $p=0.463(p>0.05)$. For the post-test, there was a substantial difference between the intervention group and the control group with $p=0,000(p<0.05)$. The assessment of dysmenorrhea in both groups had no difference. The pain would remain the same between the two groups because no intervention was given. The response can be in the form of non-pharmacological pain management, which is proven to be safer to use because it does not cause side effects like drugs because it involves physiological processes (Abunawas D. W. S \& Khotimah S., 2017). Massage therapy affects the reduction in pain intensity significantly so that the application of massage therapy is effective in reducing some of the symptoms of dysmenorrhea. This therapy will affect the motor, nervous, and cardiovascular systems, which trigger the body's resting and relaxation phases. Massage is also an effort to restore venous and lymph flow and stimulate sensory receptors in the skin and sub-skin to reduce pain (Azima et al., 2015).

The results of the study based on Table 3 shows there are differences in pain in the intervention group before and after given effleurage massage with $p<0.05$, which means there was a significant difference in dysmenorrhea before and after effleurage message was given. Effleurage massage is a non-pharmacological method that is considered effective in reducing pain. The most common dysmenorrhea pain experienced by adolescents is stiffness or spasms in the lower abdomen. This occurs due to an increase in prostaglandin (PG) F2-alpha, which is a cyclooxygenase (COX-2), which results in hypertonus and vasoconstriction in the myometrium resulting in ischemia and pain in the lower abdomen (Fernández-Martínez et al., 2018). Massage with gentle, rhythmic, gentle pressure toward the distal or lower abdomen muscles has the aim to improve blood circulation and provide strength and warm abdominal muscles (Murtiningsih \& Andani, 2018). Giving effleurage massage to the abdomen will stimulate tactile fibers in the skin so that pain signals can be inhibited. Stimulation of the skin with effleurage massage can produce messages sent through $\mathrm{A}-\delta$ fibers receptors, resulting in closed gates so that the cerebral cortex does not receive pain signals and the intensity of pain changes because these fibers can deliver pain quickly. Massage therapy affects the reduction in pain intensity significantly so that the application of massage therapy is effective in reducing some of the symptoms of dysmenorrhea. This therapy will affect the motor, nervous, and cardiovascular systems, which trigger the body's resting and relaxation phases. Massage is also an effort to restore venous and lymph flow and stimulate sensory receptors in the skin and sub-skin to reduce pain (Wulan et al., 2017).

The results of other studies stated that massage is an appropriate intervention and can reduce the intensity of pain in patients given the promising effects of massage therapy that is pain reduction, reducing tension and anxiety (Bauer et al., 2010). Effleurage massage has a distraction effect that can increase the formation of endorphins in the descending control system so that it makes it more comfortable 
Sholihah, N. R., \& Azizah, I. (2020). The Effect of Effleurage Massage on Primary Dysmenorrhea in Female Adolescent Students. JURNAL INFO KESEHATAN, 18(1), 9-17.

because of muscle relaxation (Rahmawati, 2016). Giving effleurage massage makes pain fibers that bring pain stimulus to the brain slower than broad tactile fibers and the sensation goes faster so that when touch and pain are stimulated together, the sensation of touch goes to the brain and closes the gate so that the cerebral cortex does not receive pain signals and pain intensity decreases (Rahmawati, 2016).

The decrease in pain level in progressive relaxation occurs due to relaxation, which can reduce pain intensity, increase lung ventilation, and increase blood oxygenation and stimulate endorphin secretion. This secreted endorphin relates to the "gate control" theory, which stated that a pain impulse is delivered when a defense is opened, and a pulse is inhibited when an argument is closed. From the results of the study, it was proven that there was an effect between the administration of effleurage massage on the reduction of pain in dysmenorrhea because the administration of effleurage massage in women with dysmenorrhea was interpreted as a way of pain management by closing the defense mechanism by stimulating endorphin secretion which would later inhibit the release of pain impulses (Rahmawati, 2016). Pain reduction with effleurage massage can significantly reduce the intensity of dysmenorrhea pain from 4.7 to 2.6 on the pain scale (Adiputri et al., 2018). Massage therapy is beneficial in pain management with an integrative approach that can reduce the sensation of pain and discomfort. This therapy is a complex intervention that uses many modalities by combining therapeutic relationships as an aspect of treatment. Clients are seen as active participants in themselves in one of these biopsychosocial models (Menard, 2015).

\section{CONCLUSION}

Based on data analysis that has been done, the following results are obtained: 1). There is a decrease in the level of pain in the intervention group after being given a effleurage massage from moderate to mild in 21 respondents and 8 respondents do not experience pain, 2). Effleurage massage has a significant effect on reducing the level of dysmenorrhea pain in adolescents with $\mathrm{p}<0.05(\mathrm{p}=0.000)$.

The research about the effect of effleurage massage for dysmenorrhea pain which is done to the 58 respondents showed some characterized factors. They were menarche age, menstrual duration, and family history. They were the respondents who have menstrual pain and normal menstrual cycle without any other disease. The suggestions made according to the results are below: 1) The further study about comprehensive factors of dysmenorrhea on female adolescents can be done, 2) The improved study about non-pharmacological treatment to reduce menstrual pain can be done, 3) The improvement of effleurage message as a non-pharmacological treatment to reduce pain.

\section{REFERENCES}

Abunawas, D. W. S., \& Khotimah, S. (2017). Perbedaan Pengaruh Stretching dan Massage Effleurage Terhadap Penurunan Nyeri Haid Pada Mahasiswi Fisioterapi DI UNISA Yogyakarta. Naskah Publikasi. Yogyakarta: Studi fisioterapi S1 Fakultas Ilmu Kesehatan Universitas 'Aisiyah Yogyakarta.

Adiputri, A., Darmiyanti, N. M., \& Candra, I. W. (2018). The Effectiveness of Lavender Oil Treatment Using Effleurage Massage Teqnique Towards Dysmenorrhea Intensity of Female Students at Midwifery Academy of Kartini Bali. International 
Journal of Research in Medical Sciences, 1886-1889. DOI: http://dx.doi.org/10.18203/2320-6012.ijrms20182266

Al-Matouq, S., Al-Mutairi, H., Al-Mutairi, O., Abdulaziz, F., Al-Basri, D., Al-Enzi, M., \& Al-Taiar, A. (2019). Dysmenorrhea among high-school students and its associated factors in Kuwait. BMC pediatrics, 19(1), 1-12. DOI: 10.1186/s12887019-1442-6.

Anita, W. (2017). Techniques of Pain Reduction in the Normal Labor Process: Systematic Review. Jurnal Endurance, 2(3), 362-375. DOI: 10.22216/jen.v2i3.2357.

Azima, S., Bakhshayesh, H. R., Kaviani, M., Abbasnia, K., \& Sayadi, M. (2015). Comparison of the effect of massage therapy and isometric exercises on primary dysmenorrhea: a randomized controlled clinical trial. Journal of pediatric and adolescent gynecology, 28(6), 486-491. DOI: 10.1016/j.jpag.2015.02.003.

Bajalan, Z., Moafi, F., MoradiBaglooei, M., \& Alimoradi, Z. (2019). Mental health and primary dysmenorrhea: a systematic review. Journal of Psychosomatic Obstetrics \& Gynecology, 40(3), 185-194. DOI: 10.1080/0167482X.2018.1470619.

Bauer, B. A., Cutshall, S. M., Wentworth, L. J., Engen, D., Messner, P. K., Wood, C. M., ... \& Sundt III, T. M. (2010). Effect of massage therapy on pain, anxiety, and tension after cardiac surgery: a randomized study. Complementary therapies in clinical practice, 16(2), 70-75. DOI: 10.1016/j.ctcp.2009.06.012.

Beddu, S., Mukarramah, S., \& Lestahulu, V. (2015). Hubungan status gizi dan usia menarche dengan dismenore primer pada remaja putri. SEAJOM: The Southeast Asia Journal of Midwifery, 1(1), 16-21. DOI: https://doi.org/10.36749/seajom.v1i1.53

Charu, S., Amita, R., Sujoy, R., \& Thomas, G. A. (2012). 'Menstrual characteristics' and 'Prevalence and Eff ect of Dysmenorrhea'on Quality of Life of medical student s. International Journal of Collaborative Research on Internal Medicine \& Public Health, 4(4), 276-294.

De Sanctis, V., S., Soliman, A., Bernasconi, S., Bianchin, L., Bona, G., Bozzola, M., ... \& Perissinotto, E. (2015). Primary Dysmenorrhea in Adolescents: Prevalence, Impact and Recent Knowledge. Pediatric endocrinology reviews: PER, 13(2), $512-520$.

Dhewi, S. (2016). Hubungan Stres Dan Riwayat Keluarga Dengan Kejadian Dismenore Pada Mahasiswa Di Akademi Kebidanan Bina Banua Husada Banjarbaru Tahun 2016. Jurnal Kesehatan Indonesia, 6(3), 31-33.

Faramarzi, M., \& Salmalian, H. (2014). Association of psychologic and nonpsychologic factors with primary dysmenorrhea. Iranian Red Crescent Medical Journal, 16(8). DOI: $10.5812 /$ ircmj.16307.

Fernández-Martínez, E., Onieva-Zafra, M. D., \& Parra-Fernández, M. L. (2018). Lifestyle and prevalence of dysmenorrhea among Spanish female university students. PLoS One, 13(8), 1-11. DOI: https://doi.org/10.1371/journal.pone.0201894.

Fitriana. W. N. (2017). Hubungan Tingkat Stress Dengan Kejadian Disminore Pada Mahasiswa D IV Kebidanan Semester VIII Universitas "Aisyiyah Yogyakarta. Naskah Publikasi. Yogyakarta: Program Studi Kebidanan Jenjang Diploma IV Fakultas Ilmu Kesehatan Universitas 'Aisyiyah Yogyakarta

Kural, M., Noor, N. N., Pandit, D., Joshi, T., \& Patil, A. (2015). Menstrual characteristics and prevalence of dysmenorrhea in college going girls. Journal of 
Sholihah, N. R., \& Azizah, I. (2020). The Effect of Effleurage Massage on Primary Dysmenorrhea in Female Adolescent Students. JURNAL INFO KESEHATAN, 18(1), 9-17. https://doi.org/10.31965/infokes.Vol18.Iss1.310

family medicine and primary care,4(3), 426-431. DOI: 10.4103/22494863.161345

Lestari, N. M. S. D. (2013). Pengaruh dismenorea pada remaja. In Prosiding Seminar Nasional MIPA. Halaman 323-329.

Kumalasari, M. L. F. (2017). Efektivitas Senam Dismenore Sebagai Terapi Alternatif Menurunkan Tingkat Nyeri Haid Tinjauan Sistematis Penelitian Tahun 20112016. Journal of Health Scence and Prevention, 1(1), 10-14.

Menard, M. B. (2015). Immediate effect of therapeutic massage on pain sensation and unpleasantness: a consecutive case series. Global advances in health and medicine, 4(5), 56-60. DOI: https://doi.org/10.7453/gahmj.2015.059

Murtiningsih, M., \& Andani, S. T. (2018). Difference Effect of The Combination of Lavender Aromatherapy and Effluerage with Breathing Relaxation on Pain Intensity During Labor among Primiparas. Journal of Maternity Care and Reproductive Health, 1(1), 144-159.

Rahmawati, E. (2016). Pengaruh Teknik Relaksasi Progresif Terhadap Tingkat Nyeri Haid (Dismenorhea) Pada Mahasiswi Di Universitas 'Aisyiyah Yogyakarta. Naskah Publikasi. Yogyakarta: Program Studi Ilmu Keperawatan Fakultas Ilmu Kesehatan Universitas 'Aisyiyah Yogyakarta.

Wulan, S., Soejoenoes, A., M, S. W., Hidayat, S. T., Widyawati, M. N., Gurusinga, R. (2017). The effect of effleurage and abdominal lifting massage in the labor pain. Medicine Science | International Medical Journal, 1-3. doi: 10.5455/medscience.2017.06.8670 